ISSN: 2231-3354

Received on: 05-04-2012

Revised on: 12-04-2012

Accepted on: 16-04-2012

DO: 10.7324/J APS.2012.2824
Kiran Aarelly, Manish Kumar Thimmaraju, Raghunandan Nerela Balaji Institute of Pharmaceutical Sciences Narsampet, Warangal, 506331, India.
For Correspondence

\section{Quantitative determination of Asenapine in both bulk and formulations using nautralization titrations}

\author{
Kiran Aarelly, Manish Kumar Thimmaraju, Raghunandan Nerella
}

Keywords: Asenapine, titrimetry,sodium hydroxide, potassium hydroxide, methanol.

\title{
INTRODUCTION
}

Asenapine (Org 5222, ASP) is a novel dibenzoxepinopyrrole [Trans - 5 - chloro- 2,3, 3a $12 \mathrm{~b}$ - tetra hydro - 2 - methyl - $1 \mathrm{H}$ - dibenz $(2,3: 6,7)$ oxepino - $(4,5$ - c) pyrrole $(\mathrm{Z})$ - 2 butenedioate (1:1)] (Figure 1) with unique receptor pharmacology and is available as a fastdissolving tablet for sublingual administration. It has potent dopaminergic $\left(\mathrm{D}_{1}-\mathrm{D}_{4}\right)$, serotonergic $\left(5-\mathrm{HT}_{2 \mathrm{~A}}, 5-\mathrm{HT}_{2 \mathrm{C}}, 5-\mathrm{HT}_{6}\right.$ and $\left.5-\mathrm{HT}_{7}\right)$, adrenergic $\left(\alpha_{1}\right.$ and $\left.\alpha_{2}\right)$ and histaminergic $\left(\mathrm{H}_{1}\right)$ activity, but it lacks significant anti muscarinic activity (Shahid et al., 2009). ASP is an atypical antipsychotic approved in the USA in adults for the treatment of schizophrenia and for the acute treatment, as monotherapy or adjunctive therapy to lithium or valproate; of manic or mixed episodes associated with bipolar I disorder. ASP is indicated in the European Union for the treatment of moderate to severe manic episodes associated with bipolar I disorder in adults (European Medicines Agency, 2010). In short - term trials, ASP has demonstrated superiority over placebo in the treatment of schizophrenia (Cohen, 2007, Alphs et a., 2010). and acute manic episodes associated with bipolar I disorder (Cohem et al., 2009 \& 2010). The proposed metabolism of ASP and the excretion profiles were recently published (Jacobs et al., 2011). 
The present work aims to develop a simple, rapid and sensitive, accurate and economic titrimetric method for the determination of asenapine in pure form and pharmaceutical preparations using $0.1 \mathrm{~N}$ sodium hydroxide and $0.1 \mathrm{~N}$ a potassium hydroxide solvents. These methods do not require any sample processing and extraction steps and can be used for the quality control of these drugs in industry. The developed methods were validated as per ICH guidelines and USP requirements, suitable statistical tests were performed on validation data(S Bolton,1997,J.C,Miller, 1984).

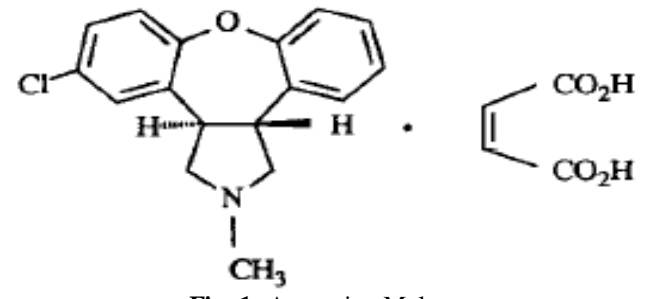

Fig. 1: Asenapine Maleate.

\section{MATERIALS AND METHODS}

Asenapine, sodium hydroxide, potassium hydroxide, methanol, phenolphthalein, potassium hydrogen phthalate, triple distilled water, starch, magnesium stearate, microcrystalline cellulose, talc

\section{Preparation of 0.1N Sodium hydroxide}

It was prepared by adding accurately weighed $4 \mathrm{gm}$ of sodium hydroxide was dissolved in $1000 \mathrm{ml}$ of distilled water using standard volumetric flask.

\section{Preparation of 0.1N Potassium hydroxide}

It was prepared by dissolving accurately weighed quantity of 5.6gm of potassium hydroxide in distilled water and volume was made up to $1000 \mathrm{ml}$ of distilled water using standard volumetric flask.

\section{Standardization of $0.1 \mathrm{~N}$ sodium hydroxide}

Accurately measured quantity of $20.4 \mathrm{gm}$ of standard potassium hydrogen phthalate and dissolved in $1000 \mathrm{ml}$ of distilled water, $5 \mathrm{ml}$ was pipette out into a clean conical flask and phenolphthalein indicator was added. Then the contents in the conical flask were titrated against standard solution of $0.1 \mathrm{~N}$ sodium hydroxide, solution. Titration was carried out until color changes from colorless to pale pink. Results were obtained in triplicate for standardization using the following formula $\mathrm{N}_{1} \mathrm{~V}_{1}=\mathrm{N}_{2} \mathrm{~V}_{2}$, (Where $\mathrm{N}_{1}$ and $\mathrm{V}_{1}$ are the normality and volume of standard potassium hydrogen phthalate $\mathrm{N}_{2}$ and $\mathrm{V}_{2}$ are the unknown normality and consumed volume of sodium hydroxide).

\section{Standardization of $0.1 \mathrm{~N}$ potassium hydroxide}

Accurately measured quantity of $20.4 \mathrm{gm}$ of standard potassium hydrogen phthalate and dissolved in $1000 \mathrm{ml}$ of distilled water, $5 \mathrm{ml}$ was pipetted into a clean conical flask and phenolphthalein indicator was added. Then the contents in the conical flask were titrated against standard solution of $0.1 \mathrm{~N}$ potassium hydroxide, solution. Titration was carried out until color changes from colorless to pale pink. Results were obtained in triplicate for standardization using the following formula $\mathrm{N}_{1} \mathrm{~V}_{1}=\mathrm{N}_{2} \mathrm{~V}_{2}$, (Where $\mathrm{N}_{1}$ and $\mathrm{V}_{1}$ are the normality and volume of standard potassium hydrogen phthalate $\mathrm{N}_{2}$ and $\mathrm{V}_{2}$ are the unknown normality and consumed volume of potassium hydroxide.

Table . 1: Aqueous titration Standardization values of the $0.1 \mathrm{~N}$ sodium hydroxide.

\begin{tabular}{llc}
\hline SNo & $\begin{array}{l}\text { Volume of potassium hydrogen } \\
\text { pthalate }(\mathbf{m l})\end{array}$ & $\begin{array}{l}\text { Volume of sodium } \\
\text { hydroxide cons umed }(\mathbf{m l})\end{array}$ \\
\hline 1 & 05 & 5.3 \\
2 & 05 & 5.1 \\
3 & 05 & 5.5 \\
\hline 1 & Mean volume of sodium hydroxide consumed & $5.2 \mathrm{ml}$ \\
2 & Standard Deviation & 0.070711 \\
3 & RSD & 1.35 \\
4 & Normality of sodium hydroxide consumed & $0.096 \mathrm{~N}$ \\
\hline
\end{tabular}

Table. 2: Standardization values of the $0.1 \mathrm{~N}$ potassium hydroxide.

\begin{tabular}{llc}
\hline SNo & $\begin{array}{c}\text { Volume of potassium Hydrogen } \\
\text { Phthalate added }(\mathbf{m l})\end{array}$ & $\begin{array}{c}\text { Volume of potassium } \\
\text { hydroxide consumed }(\mathbf{m l})\end{array}$ \\
\hline 1 & 05 & 5.1 \\
2 & 05 & 5.2 \\
3 & 05 & 5.0 \\
\hline \multicolumn{4}{c}{} \\
\hline 1 & Mean volume of potassium hydroxide consumed & $5.18 \mathrm{ml}$ \\
2 & Standard Deviation & 0.0 .08366 \\
3 & RSD & $1.61 *$ \\
4 & Molarity of potassium hydroxide consumed & $0.09 \mathrm{~N}$ \\
\hline
\end{tabular}

\section{Equivalent factors}

The exact amount of base consumed by the drug can be determined by stoichiometric equations were described in Figures $2 \& 3$. In both of these steps, one mole of drug was undergone reaction with sodium hydroxide and potassium hydroxide. Therefore, Each $1 \mathrm{ml}$ of $0.1 \mathrm{~N}$ sodium hydroxide or $0.1 \mathrm{~N}$ potassium hydroxide is equivalent to $0.04018 \mathrm{gm}$ of asenapine.

\section{Assay procedure using 0.1N sodium hydroxide}

Aliquots of asenapine were prepared by dissolving different amounts of drug (10-100mg) in $20 \mathrm{ml}$ of methanol (methanol was previously neutralized with $0.1 \mathrm{~N}$ sodium hydroxide) Aliquots were titrated using previously standardized $0.1 \mathrm{~N}$ sodium hydroxide using phenolphthalein as an indicator to pale pink was observed for end point identification. Results were obtained in triplicates and asenapine was assayed. Assay reaction for titration is shown in figure 2 .

\section{Assay procedure using 0.1N potassium hydroxide}

Aliquots of asenapine prepared by dissolving different amounts of drug(10-100mg) in $20 \mathrm{ml}$ of methanol was previously neutralized with $0.1 \mathrm{~N}$ potassium hydroxide ) aliquots were titrated using previously standardized $0.1 \mathrm{~N}$ potassium hydroxide using phenolphthalein as an indicator pale pink was observed for end point identification. Results were obtained in triplicates and asenapine was assayed. Assay reaction for titration is shown in figure 3 . 
<smiles>CN1CC2c3ccccc3Oc3ccc(Cl)cc3C2C1</smiles>

Asenapine maleate<smiles>O=C(O)/C=C\C(=O)O</smiles>

$+\mathrm{Na}-\mathrm{OH} \stackrel{\text { methanol }}{\longrightarrow}$

$\mathrm{Cl}$<smiles>COCC=CC(C=CC(=O)O)OC</smiles>

sodium salt asenapine maleate

Fig. 2: Neutralization titration with sodium hydroxide.<smiles>CN1CC2c3ccccc3Oc3ccc(Cl)cc3C2C1</smiles>

Asenapine maleate<smiles>O=C(O)/C=C\C(=O)O</smiles>

potassium hydroxide<smiles>[X]OC(=O)/C=C/C(=O)O</smiles>

potassium salt of Asenapine maleate

Fig. 3: Neutralization titration with potassium hydroxide.

Table. 3: Assay of Asenapine with $0.1 \mathrm{~N}$ sodium hydroxide.

\begin{tabular}{|c|c|c|c|c|c|c|}
\hline SNo & Amount of asenapine added (mg) & $\begin{array}{r}\text { Mean volume of sodium } \\
\text { consumed }(\mathrm{ml})\end{array}$ & droxide & RSD*(mg) & Mean amount found $(\mathrm{mg}) \dagger$ & \% Recovery \\
\hline 1 & 10 & $0.27 \pm 0.004$ & & 2.03 & 102.86 & 102.86 \\
\hline 2 & 20 & $0.56 \pm 0.02$ & & 1.51 & 205.71 & $102 . .35$ \\
\hline 3 & 40 & $1.1 \pm 0.04$ & & 1.84 & 407.62 & 101.90 \\
\hline 4 & 80 & $2.2 \pm 0.2$ & & 2.3 & 800.00 & 100.00 \\
\hline 5 & 100 & $2.8 \pm 0.1$ & & 1.88 & 1028.90 & 102.89 \\
\hline SNo & $\begin{array}{c}\text { Blend equivalent } \\
\text { (mg) }\end{array}$ & $\begin{array}{l}\text { Mean volume of sodium } \\
\text { hydroxide consumed }(\mathrm{ml})\end{array}$ & RSD*$^{*}(\mathbf{m g})$ & \multicolumn{2}{|c|}{ Mean amount found $(\mathrm{mg}) \dagger$} & \% Recovery \\
\hline 1 & $200 \mathrm{mg}$ & $0.56 \pm 0.03$ & 1.45 & \multirow{2}{*}{\multicolumn{2}{|c|}{$\begin{array}{l}205.71 \\
400.00\end{array}$}} & 102.85 \\
\hline 2 & $400 \mathrm{mg}$ & $1.14 \pm 0.04$ & 1.34 & & & 100.00 \\
\hline
\end{tabular}

*Relative standard deviation $(\mathrm{n}=5)$

$\dagger$ Each $1 \mathrm{ml}$ of $0.1 \mathrm{~N}$ S0dium hydroxide is equivalent to $0.04018 \mathrm{gm}$ of asenapine

Table. 4: Assay of Asenapineby with $0.1 \mathrm{~N}$ potassium hydroxide

\begin{tabular}{|c|c|c|c|c|c|}
\hline SNo & $\begin{array}{l}\text { Amount of asenapine added } \\
(\mathrm{mg})\end{array}$ & $\begin{array}{l}\text { Mean volume of potassium } \\
\text { hydroxide consumed }(\mathrm{ml})\end{array}$ & RSD*(mg) & Mean amount found (mg) $\dagger$ & \% Recovery \\
\hline 1 & 10 & $0.27 \pm 0.02$ & 1.88 & 101.05 & 101.05 \\
\hline 2 & 20 & $0.57 \pm 0.04$ & 1.69 & 205.71 & 102.86 \\
\hline 3 & 40 & $1.1 \pm 0.15$ & 1.68 & 396.99 & 99.25 \\
\hline 4 & 80 & $2.2 \pm 0.25$ & 2.21 & 793.98 & 99.25 \\
\hline 5 & 100 & $2.66 \pm 0.26$ & 2.05 & 1013.52 & 101.35 \\
\hline SNo & $\begin{array}{c}\text { Blend equivalent } \\
\text { (mg) }\end{array}$ & $\begin{array}{l}\text { Mean volume of potassium } \\
\text { hydroxide consumed }(\mathrm{ml})\end{array}$ & RSD*(mg) & Mean amount found (mg) & \% Recovery \\
\hline 1 & $200 \mathrm{mg}$ & $0.57 \pm 0.02$ & 1.48 & 205.71 & 102.86 \\
\hline 2 & $400 \mathrm{mg}$ & $1.12 \pm 0.24$ & 1.88 & 404.21 & 101.05 \\
\hline
\end{tabular}

*Relative standard deviation $(\mathrm{n}=5)$

$\dagger$ Each $1 \mathrm{ml}$ of $0.1 \mathrm{M}$ potassium hydroxide is equivalent to $0.04018 \mathrm{gm}$ of asenapine 


\section{Linearity}

To establish the linearity of proposed methods, five separate series of solutions of drug ranging from $10 \mathrm{mg}-100 \mathrm{mg}$ were dissolved in $20 \mathrm{ml}$ of previously neutralized methanol and add $10 \mathrm{ml}$ of distilled water. Then the resulting solution was titrated against $0.1 \mathrm{~N}$ sodium hydroxide and $0.1 \mathrm{~N}$ potassium hydroxide by using phenolphthalein as an indicator, end point pale pink color.

\section{Specificity}

Specificity is the ability of an analytical method to differentiate and quantify the analyte in the presence of other components in the sample (Chandran et al., 2007).

The specificity of these methods were determined by adding inert excipients such as starch, microcrystalline cellulose, magnesium stearate and talc individually with known concentration of the drug and titrated by using standard solutions.

\section{Estimation from excipient blends}

The in-house prepared tablet formulation blends were prepared, since no marketed formulations were available. These tablet blends were prepared by adding immediate release excipients such as starch, microcrystalline cellulose, magnesium stearate and talc. The crushed blend equivalent $200 \mathrm{mg}$ and $400 \mathrm{mg}$ were transferred to conical flask and respective solvents were added; solutions were filtered through Whatman filter paper number (\#40) and the filtrate was titrated with standard solutions using indicator. Simultaneous blank determinations were conducted to confirm specificity and to nullify the effect of each ingredient. Assay results were shown in Table 3 and 4. Calibration curves were shown in figure- 4 and 5

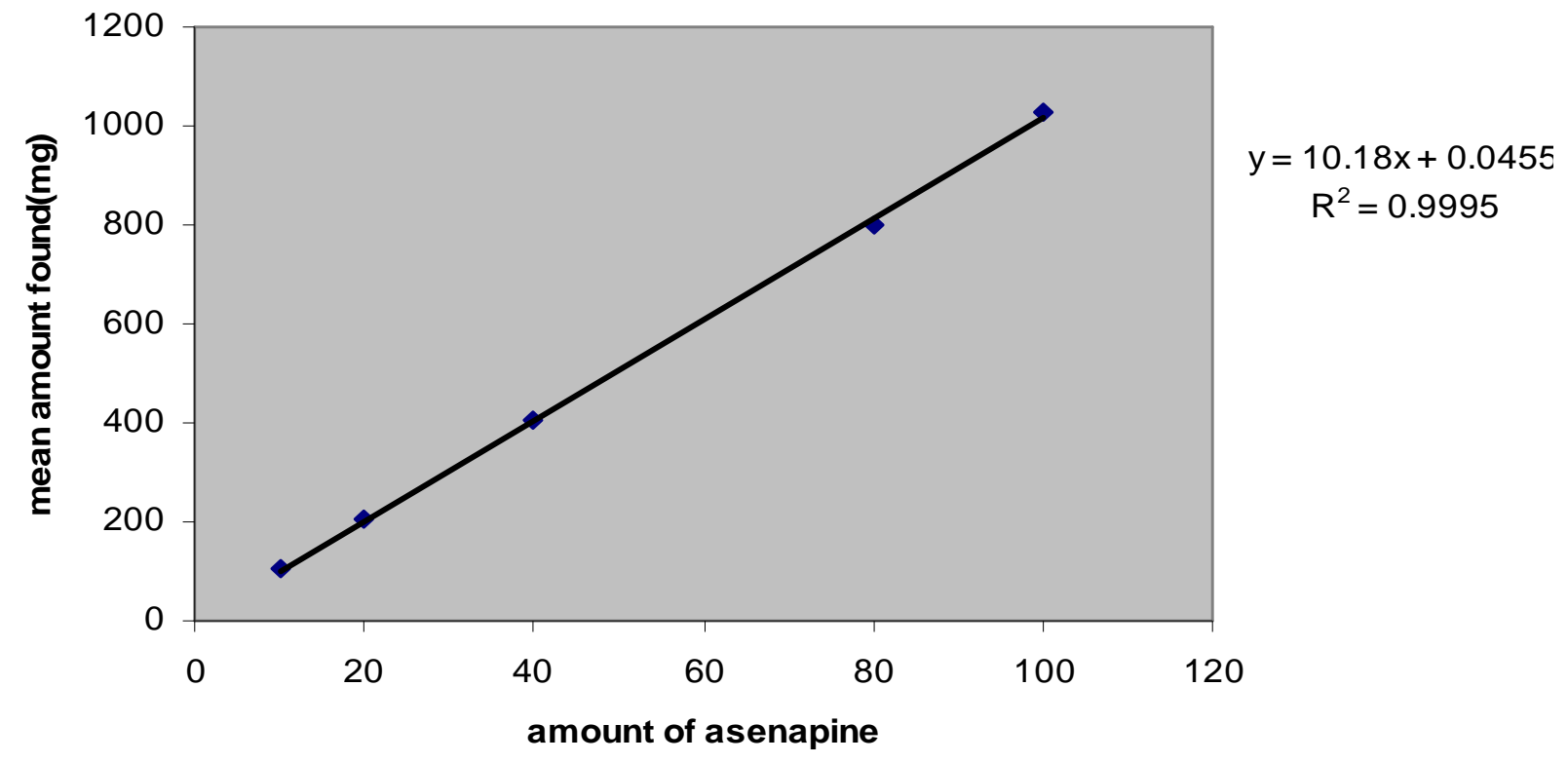

Fig. 4: Calibration curve- Assay of Asenapine with $0.1 \mathrm{~N}$ sodium hydroxide.

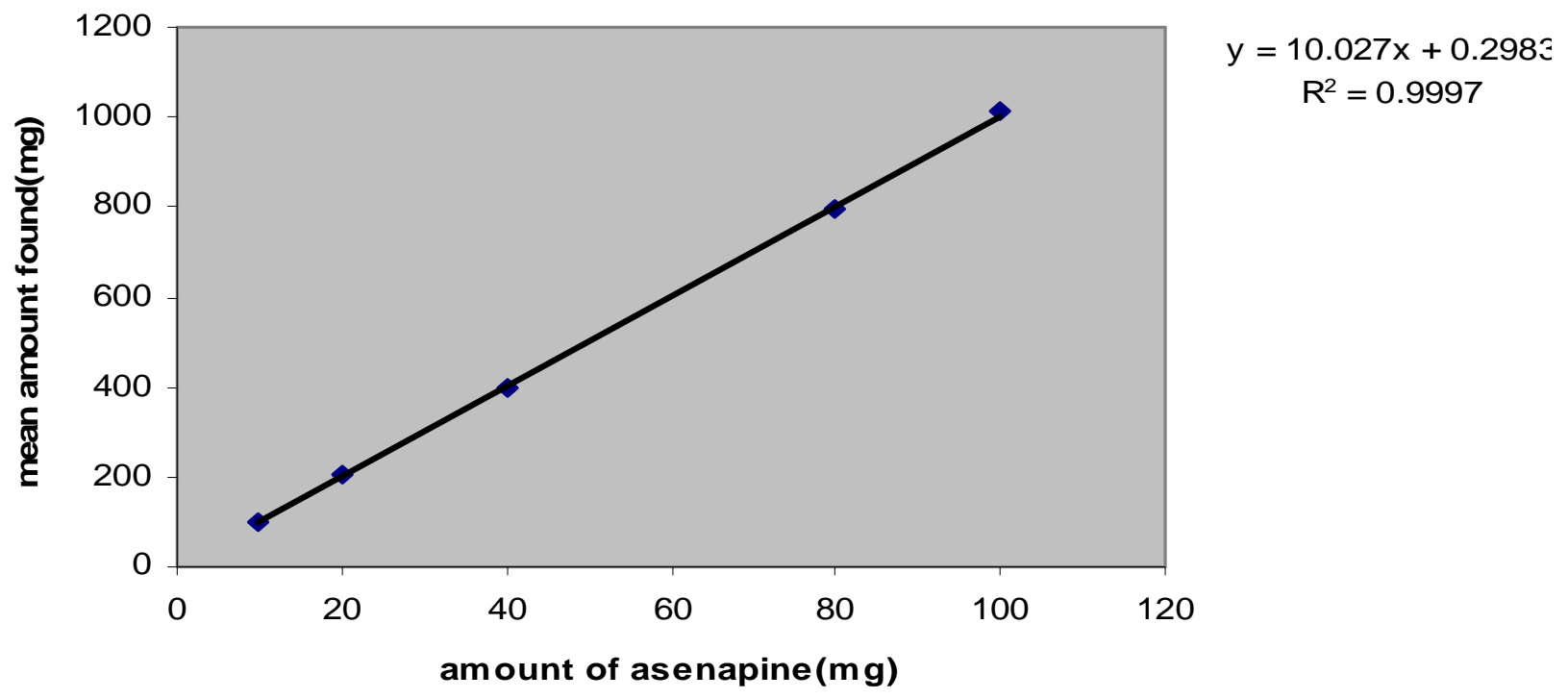

Fig. 5: Calibration curve- Assay of Asenapine with $0.1 \mathrm{~N}$ potassium hydroxide. 


\section{RESULTS \& DISCUSSIONS}

The mean five normality values are calculated and approximate values obtained, which were equivalent to normality of 0.1 . Methanol was used to dissolve asenapine .Add $10 \mathrm{ml}$ of distilled water, did not produce any precipitate. The proposed reactions were found to be simple neutralization of asenapine using basic solvents like sodium hydroxide and potassium hydroxide. During the process of titration, the amount of base consumed was calculated.

\section{Specificity \& Linearity}

An accurately consumed $1.33 \pm 0.04 \mathrm{ml}$ (RSD 1.3) of $0.1 \mathrm{~N}$ sodium hydroxide is equivalent to $506.66 \mathrm{mg}$ of asenapine and $1.34 \pm 0.05 \mathrm{ml}$ (RSD 1.61) of $0.1 \mathrm{~N}$ potassium hydroxide is equivalent to $510.47 \pm 1.2 \mathrm{mg}$ of asenapine respectively. The correlation coefficient was found to be 0.9995 for $0.1 \mathrm{~N}$ sodium hydroxide and 0.9997 for 0.1 ppotassium hydroxide..

\section{Assay \& Recovery studies}

The assay procedure was performed and percent recovery values were determined for actual drug and blend equivalents (Table 3 and 4). The estimated drug content with extremely low value of RSD established the precision of the proposed methods. Recovery experiments using the developed assay procedures further indicated absence of interference from pharmaceutical excipients used in the selected formulation blends.

\section{CONCLUSION}

A new titrimetric method has been developed to be routinely applied to estimate in asenapine bulk and formulation.
These methods have proved to be specific, linear, well recovered.Hence the method is recommended for routine quality control analysis.

\section{REFERENCES}

Chandran, S., Singh, S.P. Comparison of various international or analytical method validation. Pharmazie 2007; 62, 4-14.

European Medicines Agency.Sycrest asenapine. 2010. Available from.http://www.ema.europa.eu/ema/index.jsp?curl=pages/medicines/hum an/medicines/001177/human_med_001379.jsp\&murl=menus/medicines $/ \mathrm{m}$ edicines.jsp \& mid=WC0b01ac058001d124\&jsenabled=true , accessed 28 September 2010.

J.C. Miller,J.N.Miller, in Statistics for analytical chemistry, $2^{\text {nd }}$ ed,Wiley,New york,(1984) 83-11

Kane JM, Cohen M, Zhao J, Alphs L, Panagides J.Efficacy and safety of asenapine in a placebo- and haloperidol-controlled trial in patients with acute exacerbation of schizophrenia.Journal of Clinical Psychopharmacology. 2010; 30: 106-115.

McIntyre RS, Cohen M, Zhao J et al A 3-week, randomized, placebo-controlled trial of asenapine in the treatment of acute mania in bipolar mania and mixed states.Bipolar Disorder. 2009a; 11: 673-686.

McIntyre RS, Cohen M, Zhao J et al.Asenapine in the treatment of acute mania in bipolar I disorder: a randomized, double-blind, placebocontrolled trial. Journal of Affective Disorders. 2010; 122: 27-38.

Potkin SG, Cohen M, Panagides J.Efficacy and tolerability of asenapine in acute schizophrenia: a placebo- and risperidone-controlled trial.Journal of Clinical Psychiatry. 2007; 68:1492-1500.

Saphris ${ }^{\circledR}$.Asenapine sublingual tablets. Full prescribing information. Schering Corporation, a subsidiary of Merck \& Co. Inc. 2010. Whitehouse Station, NJ0. Available from: http://www.spfiles.com/ pisaphrisv1. pdf. Accessed January 2011.

Shahid M, Walker GB et al. Asenapine: a novel psychopharmacologic agent with a unique human Receptor signature.Journal of Psychopharmacology. 2009; 23: 65-73

S.Bolton, in: pharmaceutical statistics:practical and clinical applications, $3^{\text {rd }}$ edition,Marcel Dekker, New york,1997,pp.216-264.

Van de Wetering-Krebbers SFM, Jacobs PL, Kemperman GJ et al. Metabolism and excretion of asenapine in healthy male subjects.Drug Metabolism and Disposition. 2011; 39: 580 - 590. 